\title{
Oral Sources and the History of Mexican Workers in the United States
}

\section{Devra Weber}

University of California, Los Angeles

Historians writing the history of Mexican workers in the United States face a discouraging paucity of written documentation. Most early twentieth century sources on Mexican labor focused on the impact of Mexican labor on the economy, work force, and society, but left unasked and unanswered fundamental questions about Mexican working people, their communities, and internal labor organization. ${ }^{1}$

Under the pressure of political struggles in the 1960s the focus of Mexican studies began to change. Social scientists began to focus on Mexicans as active historical participants. They asked new questions which challenged the traditional stereotypes of Mexican working people. New written sources were located and old sources used in new ways. But written documentation was often clearly insufficient to answer questions about workers' lives, questions about class consciousness, questions about the social and political dynamics within the Mexican communities. Even simply factual questions about work and labor organization often evaded the historian searching in more traditional documentation. For these questions, oral histories became a pivotal source.

Oral sources have been used to write or substantially revise the history of Mexican workers. What follows is a brief discussion drawn from my own work to illustrate the value of oral sources in writing the history of Mexican workers.

In my article, "The Organization of Mexicano Agricultural Workers in the Imperial Valley and Los Angeles, 1928-1934: An Oral History Approach" I focused on Mexican participation in three agricultural strikes. These strikes were used to explore the nature of Mexican class consciousness, leadership, and labor organization. I used newspapers, federal documents and other secondary sources, but oral sources were the basis for the study. ${ }^{2}$

Prior studies of these strikes had been distorted by the inadequacies of available documentation and the limited perspectives of many, although not all, earlier historians. With the exception of Ron Lopez's article on the El Monte berry strike of 1933 which relied heavily on oral sources, historical studies had attributed classconscious organizing and agricultural strike leadership to the Anglo organizers of the Cannery and Agricultural Workers Industrial Union of the United States 
Communist Party. Most other reports and studies of the strike, some sympathetic and some not, argued that the Mexican workers blindly followed Anglo leadership. New questions asked of oral sources were able to shatter these misconceptions. ${ }^{3}$

First, oral sources made it clear that class-conscious Mexican organizers were active in agricultural strikes of the 1920s and 1930s. Informants remembered Mexican agricultural labor organizers, socialists, communists and anarcho-syndicalists who had participated in struggles on both sides of the border for more than two decades. The organizers themselves provided rich information about the nature of the Mexican left-wing community in California during this period, their influence in labor organizing, and their relation with non-Mexican leftists.

Second, the interviews revealed Mexican organizational and ideological influences. One important influence was the anarcho-syndicalist Partido Liberal Mexicano, prominent in labor organization in Mexico, pivotal in the Mexican revolution, and active after 1904 from its base in exile in the United States. Despite United States government repression of the organization, the ideological and organizational legacy remained a perhaps waning but still potent influence in the 1930s. By the turbulent 1930s an increasingly vital leftist influence came from Mexican Communists active in labor organization. Mexican workers formed Mexican Communist cells in southern California barrios which were a focus for study and labor organizing.

Individual workers and organizations formed working alliances with their non-Mexican counterparts, relations strained at times by racial and cultural chauvinism. Mexicans frequently held dual membership in left-wing organizations, such as one worker who held membership in the Partido Liberal Mexicano, the Industrial Workers of the World and later the Communist Party, USA. Despite the growing strength of these alliances north of the border, ideological and organizational ties of individuals and groups reached into Mexico as well.

Third, the interviews clarified the role class-conscious Mexicans played in labor organization. Mexican working-class anarchists and Communists organized on the job and formed loose networks of migratory organizers throughout California. These men and women were crucial in the strikes which broke out in the 1930s, and pivotal in the role Cannery and Agriculture Workers Industrial Union, allied with the CPUSA, played in these strikes. In the Imperial Valley lettuce strike of 1934, for example, Mexican workers formed a left faction within the Mexican strike committee. Some were members of the local Mexican Communist cell. A delegation from this faction went to Los Angeles to request fraternal help from the Communist Party, and returned to the Valley with Communist organizers Stanley Hancock and Dorothy Ray. Despite both current and historical allegations to the contrary, both the Anglo and Mexican organizers concur that Mexican led the strike and made both strategic and tactical decisions. Similar patterns of alliances occurred in the massive agricultural strike waves in California during the 1930s as well as other areas of organization.

And finally, interviews with workers help to understand why thousands of Mexicans, many facing deportation, went on strike against the organized power of 
California growers and police. In 1933, for example, over 18,000 cotton workers went on strike for over a month in what amounted to a general strike in California's agricultural heart, the San Joaquin Valley. While Mexican and Anglo organizers were active, many of the strikers had never heard of the union. Yet they expressed support and frequently militant solidarity despite the obstacles they faced. One woman remembered why they joined the strike in the depth of the depression, despite her family's dwindlng supply of money, food, and gas to get home: "This was in '33 ... We didn't know what union it was or who was organizing or nothing. We just knew that there was a strike and that we were not going to break a strike. That's all we knew." The Mexican working-class community was by no means homogeneous. Some Mexican foremen, contractors, and strike breakers had, at best, ambivalent relations to the strike and strikers. Yet oral sources can help understand why Mexican workers, still so close to their own national revolution, went on strike in California. They can help delineate the contours of Mexican working-class culture, and the contraditions and conflicts within Mexican workingclass communities north of the Rio Bravo which shaped them.

While oral sources have been pivotal in studies about Mexican workers, their full potential has yet to be reached. This stems in part from their richness and deceptive simplicity which has often lured historians into ignoring the nature and limitations as well as the full potential of oral sources. Oral 'history' is in some respects a misnomer. While oral sources may constitute individual histories, they remain one among many historical sources for writing a collective history. As sources they are most compelling in what they can reveal about people's relation to their past and to history, in short what they reveal about consciousness. But their unique strength is also suggestive of their limitations.

Our concern with making history accessible is itself a recognition that people have been denied a sense of their own history, an alienation often reflected in oral narratives. Frequently people individualize their lives and experience, and their perspectives often exclude or diminish a broader historical framework. Certainly there are exceptions. Oral narratives with class-conscious workers and socialists often present an historical understanding and framework. Yet for the most part, the uncritical use of oral histories runs the risk of reinforcing people's alienation from the historical process by presenting oral sources isolated from a broader historical framework. ${ }^{4}$

Oral sources, as other sources, need to be understood wthin a broad historical framework encompassing institutional and class relations. A study which has successfully interwoven oral sources within a broader framework is "Women at Farah: An Unfinished Story." The authors conducted over seventy hours of interviews with Mexican women who in 1972 went on strike against Texas pant manufacturer Willie Farah. The study focused on the changing perceptions of the women, of themselves as workers, women, and Mexicans, and their changing perceptions of and relations with their supervisors, other workers, their families, and communities. The interviews are the basis for the article, yet the study's strength lies in their integration into the broad historical, social, and economic context of South Texas, 
the Farah plant, and the problems of labor organization in the highly competitive clothing industry. ${ }^{5}$

This work is representative of other creative work with oral sources being done in Mexican history. Oral sources are being used for studies on Mexican workers in canneries, garment shops, agricultural fields, and mines of the southwest, as well as the heavy industries of the midwest. Raquel Goldschmidt of Pima College is conducting oral narratives with Mexican women active in Arizona's mining communities in the teens. Roberto Calderon of UCLA is recording narratives of Mexican miners in South Texas. I have been collecting oral histories with California cotton workers and organizers active in the 1933 cotton strike.

Oral narratives are being conducted with Mexican labor organizers. Among these are the extensive interviews Alberto Camarillo of Stanford has conducted with CIO organizer Luisa Moreno. Emilio Zamora has interviewed members of the South Texas Agricultural Worker's Union of the 1930s. Emma Perez of UCLA has begun to collect oral narratives of women active in the Partido Liberal Mexicano in the teens and twenties. Luis Arroyo of UC Davis has used a series of oral histories with Mexican furniture workers and organizers. Victor Nelson-Cisneros of Colorado College has relied on oral sources for his study on the United Cannery and Packing and Agricultural Workers of America in the 1930s.

Oral sources can unearth new evidence, reveal stratums of historical process undetected through other methods, and can yield the rich texture of daily life, work, and social relations. They provide insight into consciousness and culture, revealing people as active, reflective, and conscious participants at the center of historical process and transformation. Judiciously and creatively used, and integrated into the broader historical framework encompassing institutional and social relations, struggle, and change, these sources promise to facilitate the creation of a critical history of Mexican workers in the United States and, by extension, broaden our historical understanding of the United States working class as a whole.

\section{NOTES}

1. In terminology, I follow the lead of Mexican workers in the United States who, through the thirties, referred to themselves as Mexicans regardless of citizenship or legal status.

2. Devra Anne Weber, "The Organization of Mexicano Agricultural Workers in the Imperial Valley and Los Angeles, 1928-1934: An Oral History Approach." Aztlan: Chicano Journal of the Social Sciences and the Arts. 3 (1972).

3. Ronald Lopez. "The El Monte Berry Strike of 1933," Aztlan: Chicano Journal of the Social Sciences and the Arts. 1 (1970).

4. For an excellent discussion of these issues see Michael H. Frisch, "The Memory of History," Radical History Review, 25 (1981), 9-26; and Michael Frisch, "Oral History and Hard Times, A Review Essay," Red Buffalo, 1 and 2 (n.d.), 230.

5. Laurie Coyle, Gail Hershatter, Emily Honig, "Women at Farah: An Unfinished Story," in Mexican Women in the United States: Struggles Past and Present, Magdalena Mora and Adelaida de Castillo (eds.), (Chicano Studies Research Center, UCLA, 1980), 117-145. 